\section{Hearsay Evidence}

Nathalie DeFabrique

Cook County Department of Corrections,

Chicago, IL, USA

\section{Synonyms}

Federal rules of evidence

\section{Definition}

Hearsay is generally considered unverified information heard or received from another. As it relates to the law, hearsay evidence is a legal principle involving the reiteration of statements made out of court and the possible admission of those statements in court. In general, hearsay is based on the reports of others rather than the personal knowledge of a witness and therefore generally not admissible as testimony.

A common misconception is that hearsay evidence is never permitted in judicial proceedings.
While it is accurate that it is generally not accepted, there are some exemptions. For example, not all out of court statements are considered hearsay. If a statement is used for purposes other than to prove the truth of assertion, it can be admissible in judicial proceedings. The statement is considered hearsay if it is offered to prove the truth of what the statement claims. Another fallacy regarding hearsay is that it only applies to oral statements. However, it also includes written statements or nonverbal conduct of a person.

\section{Cross-References}

Admissibility

\section{References and Readings}

FRE 804(b)(3).

Rule 801, 28 U.S.C. App. See Rule for Courts-Martial 801, Manual for Court Martial, United States (2005 ed.).

Wigmore on Evidence $§ 1360$. 